\title{
Henri de Régnier, Francis Jammes, Correspondance (1893-1936)
}

\section{Ida Merello}

\section{Q OpenEdition}

1 Journals

\section{Edizione digitale}

URL: http://journals.openedition.org/studifrancesi/557

DOI: 10.4000/studifrancesi.557

ISSN: 2421-5856

\section{Editore}

Rosenberg \& Sellier

\section{Edizione cartacea}

Data di pubblicazione: 1 aprile 2015

Paginazione: 181

ISSN: 0039-2944

\section{Notizia bibliografica digitale}

Ida Merello, « Henri de Régnier, Francis Jammes, Correspondance (1893-1936) », Studi Francesi [Online], 175 (LIX | I) | 2015, online dal 01 avril 2015, consultato il 18 septembre 2020. URL : http:// journals.openedition.org/studifrancesi/557 ; DOI : https://doi.org/10.4000/studifrancesi.557

Questo documento è stato generato automaticamente il 18 settembre 2020.

\section{(c) (i) $\odot$}

Studi Francesi è distribuita con Licenza Creative Commons Attribuzione - Non commerciale - Non opere derivate 4.0 Internazionale. 


\title{
Henri de Régnier, Francis Jammes, Correspondance (1893-1936)
}

\author{
Ida Merello
}

\section{NOTIZIA}

HENRI DE RÉGNIER, FRANCIS JAMMES, Correspondance (1893-1936), édition de Pierre LACHASSE, Paris, Classiques Garnier 2014, pp. 244.

1 Il volume completa la corrispondenza di Régnier con André Gide (1997), con Pierre Louÿs (2012) con Viélé-Griffin (2012, a cura di pierre LACHASSE), e raccoglie centottantasette lettere inedite, conservate in larga parte alla biblioteca Doucet e all' Institut de France. Si tratta di una corrispondenza significativa non solo dei rapporti tra i due autori, ma anche espressiva dei loro caratteri. P. LACHASSE ha messo molto bene in luce l'ombrosità di Jammes, che si rivolge a Régnier solo per sollecitare recensioni o spazi su quotidiani e periodici, ma teme che l'altro possa in realtà complottare per ostacolare la sua ascesa; mentre Régnier appare sempre come un gran signore, che passa sopra alle piccole meschinità, ed esprime delle riserve su Jammes solo quando le innovazioni formali gli sembrano troppo spinte, o quando la militanza religiosa gli pare soffocare lo spirito poetico. Dal canto suo Jammes apprezza la tendenza di Régnier a una sempre maggiore clarté, e lo ricollega alla tradizione classica. LACHASSE rende così conto di un'amicizia fondata sui rapporti letterari, talvolta difficile e interrotta, sorretta tuttavia da una reciproca stima. 